\title{
Article \\ Seed Priming and Coating by Nano-Scale Zinc Oxide Particles Improved Vegetative Growth, Yield and Quality of Fodder Maize (Zea mays)
}

\author{
Manisha Tondey ${ }^{1}$, Anu Kalia ${ }^{2}, * \mathbb{C}$, Alla Singh ${ }^{3}$, Gurmeet Singh Dheri ${ }^{4}$, Monica Sachdeva Taggar ${ }^{5}$, \\ Eugenie Nepovimova ${ }^{6}$, Ondrej Krejcar ${ }^{7,8}{ }^{(1)}$ and Kamil Kuca ${ }^{6, *}$ (D)
}

check for updates

Citation: Tondey, M.; Kalia, A. Singh, A.; Dheri, G.S.; Taggar, M.S.; Nepovimova, E.; Krejcar, O.; Kuca, K. Seed Priming and Coating by Nano-Scale Zinc Oxide Particles Improved Vegetative Growth, Yield and Quality of Fodder Maize (Zea mays). Agronomy 2021, 11, 729. https://doi.org/10.3390/ agronomy11040729

Academic Editors:

Sanghamitra Majumdar and Luca Pagano

Received: 28 February 2021

Accepted: 6 April 2021

Published: 9 April 2021

Publisher's Note: MDPI stays neutral with regard to jurisdictional claims in published maps and institutional affiliations.

Copyright: (c) 2021 by the authors. Licensee MDPI, Basel, Switzerland. This article is an open access article distributed under the terms and conditions of the Creative Commons Attribution (CC BY) license (https:// creativecommons.org/licenses/by/ $4.0 /)$.
1 Department of Microbiology, Punjab Agricultural University, Ludhiana, Punjab 141004, India; tondeymanisha@gmail.com

2 Electron Microscopy and Nanoscience Laboratory, Department of Soil Science, Punjab Agricultural University, Ludhiana, Punjab 141004, India

3 ICAR- Indian Institute of Maize Research, Punjab Agricultural University Campus, Ludhiana, Punjab 141004, India; allasingh.panesar@gmail.com

4 Green House Gas Laboratory, Department of Soil Science, Punjab Agricultural University, Ludhiana, Punjab 141004, India; gsdheri@pau.edu

5 Department of Renewable Energy Engineering, Punjab Agricultural University, Ludhiana, Punjab 141004, India; monicasachdeva@pau.edu

6 Department of Chemistry, Faculty of Science, University of Hradec Kralove, 50003 Hradec Kralove, Czech Republic; eugenie.nepovimova@uhk.cz

7 Center for Basic and Applied Science, Faculty of Informatics and Management, University of Hradec Kralove, 50003 Hradec Kralove, Czech Republic; ondrej.krejcar@uhk.cz

8 Malaysia Japan International Institute of Technology (MJIIT), Universiti Teknologi Malaysia, Jalan Sultan Yahya Petra, Kuala Lumpur 54100, Malaysia

* $\quad$ Correspondence: kaliaanu@pau.edu (A.K.); kamil.kuca@uhk.cz (K.K.); Tel.: +91-2401960 (A.K.); +420-603-289-166 (K.K.)

Abstract: Nano-fertilizers of essential plant nutrients, including micronutrients, have the potential to improve nutrient use efficiency and productivity of field crops in deficient soils. The present study reports the comparative influence of zinc oxide nanoparticles ( $\mathrm{ZnONPs}$ ) and bulk $\mathrm{Zn}$ salt $\left(\mathrm{ZnSO}_{4}\right)$ on the growth, yield, and quality of fodder maize (Zea mays) (var. J-1006) cultivated under field conditions in the year 2019. Three levels $\left(0,20\right.$, and $\left.40 \mathrm{mg} \mathrm{L}^{-1}\right)$ of $\mathrm{Zn}$ fertilizers were used for seed priming and coating in triplicate following the randomized complete block design model. An increase in vegetative and yield parameters (number of plants, plant height, stover yield, plant biomass), acid detergent fiber $(\mathrm{ADF} \%)$, and hemicellulose contents and shoot zinc $(\mathrm{Zn})$ content on treatment of seeds with $\mathrm{ZnONPs}\left(20 \mathrm{mg} \mathrm{L}^{-1}\right)$ concentration as compared to bulk $\mathrm{ZnSO}_{4}$ and control treatments was observed. The application of ZnONPs $\left(40 \mathrm{mg} \mathrm{L}^{-1}\right)$ significantly enhanced the total chlorophyll content, available soil nitrogen and phosphorus, neutral detergent fiber (NDF\%), and cellulose contents and improved the total soil microbial counts and soil enzyme activities (dehydrogenase, acid and alkaline phosphatase enzyme activities), whereas a significant increase in available soil potassium and zinc contents was recorded under ZnONPs $\left(20 \mathrm{mg} \mathrm{L}^{-1}\right)$ treatments. These findings suggest an encouraging effect on the growth and yield attributing characteristics of fodder maize after ZnONPs seed coating at low concentration. Furthermore, ZnONPs seed coating can also be considered an effective tool for the delivery of $\mathrm{Zn}$ micronutrient to fodder maize crop.

Keywords: enhanced biomass; forage crop; fortification; nano-micronutrient; seed treatment

\section{Introduction}

Maize (Zea mays L.), a high nutrient demanding crop, requires balanced nutrition, particularly the requirement for micronutrients such as zinc is substantial [1,2]. The zinc requirement is manifested as high susceptibility of maize to exhibit zinc $(\mathrm{Zn})$ deficiency 
disorders and, therefore, maize is considered as a Zn deficiency indicator plant [3]. The Zn requirement for improved plant growth and development is well established [2]. It plays a vital role in the production of biomass through its influence on diverse physiological and metabolic processes such as chlorophyll formation, fertilization, and germination [4]. Biochemically, $\mathrm{Zn}$ is an essential and integral component of the cytochrome complex and is also required for nucleotide synthesis and membrane integrity [5]. At the plant physiology scale, $\mathrm{Zn}$ is needed as a cofactor or complexing ion for efficient working of all the six groups of enzymes [6]. Furthermore, $\mathrm{Zn}$ is required as a precursor for the synthesis of the auxin phytohormone [7] and thus has a role in the promotion of vegetative growth in plants. These studies invariably establish the benefits and the requirement of $\mathrm{Zn}$ for plants. Therefore, $\mathrm{Zn}$ deficiency will lead to cessation or improper functioning of various metabolic and physiological processes in crop plants.

Soils exhibiting low zinc availability are prevalent in tropical and semi-tropical countries affecting approximately 50\% of the land across globe. Intensive cultivation of cereal crops in low organic carbon containing light or sandy and high $\mathrm{pH}$ calcareous soils has been responsible for the low available $\mathrm{Zn}$ contents. The low soil $\mathrm{Zn}$ availability leads to the appearance of characteristic zinc deficiency symptoms in crop plants which includes yellowing of leaves, stunted plant growth, and reduced grain yield $[8,9]$. Therefore, the application of water-soluble $\mathrm{Zn}$ fertilizer such as zinc sulfate $\left(\mathrm{ZnSO}_{4}\right)$ as a basal dose is a common practice to fulfill the $\mathrm{Zn}$ requirement of crops [10]. However, quick $\mathrm{Zn}$ fixation/precipitation due to interaction with the calcium $\left(\mathrm{Ca}^{2+}\right)$, phosphate $\left(\mathrm{PO}_{4}{ }^{2-}\right)$ and carbonate $\left(\mathrm{CO}_{3}{ }^{2-}\right)$ ions in the soil [11] and leaching (horizontal/vertical soil zones) particularly in sandy soils [12] from the soil surface after application of conventional Zn fertilizers renders $\mathrm{Zn}$ unavailable for uptake by the crop plants [13]. A possible alternative can be the development and use of slow or controlled release $\mathrm{Zn}$-formulations besides the nano-scale Zn formulations [6,14,15].

Zinc oxide nanoparticles (ZnONPs) are the most common nano-Zn formulations that have been prepared, applied, and evaluated for their plant growth-promoting properties in recent years [16,17]. The mode of application of ZnONPs involves soil, foliar, and seed treatments [18]. Among these application modes, the seed invigoration treatments, including seed priming and coating with ZnONPs are considered relatively eco-safe and economically prudent [18]. These seed treatments include supplementation of ZnONPs at low concentrations leading to adsorption of ZnONPs on the surface of the seed coat followed by their penetration and movement through seed tissue layers which significantly improves germination and crop biomass [17]. Therefore, seed priming and coating is a targeted delivery approach to enhance the availability of micronutrients or other elements during the early growth of the plants [19]. Cultivation practices combining novel seed invigoration technologies and precision farming can improve the seed germination potential, seedling vigor and development, photosynthesis, and reproductive growth to ensure enhanced yield [20-22].

Several recent reports identified the positive impact of foliar application of nano- $\mathrm{Zn}$ formulations in different cereal and horticultural crops [16-19,22]. These reports indicate a clear trend for the development of nano-based seed invigoration treatments possibly due to bio- and eco-safety aspects attached to handling and foliar application of the nano- $\mathrm{Zn}$ particles which could be better addressed through seed invigoration techniques. The present research intervention involves the synthesis of $\mathrm{ZnO}$ nanoparticles by the wet chemistry technique. The synthesized ZnONPs were characterized to establish their nanoscale dimensions and properties through diverse spectroscopy and microscopy techniques. The characterized ZnONPs nano-formulations and the conventional zinc sulphate $\left(\mathrm{ZnSO}_{4}\right)$ fertilizer were then utilized as seed priming and coating treatments to evaluate the efficiency of the nano-scale $\mathrm{Zn}$ fertilizer and its effect on the fodder maize crop grown under field conditions. Further, the work compares the relative impact of $\mathrm{ZnSO}_{4}$ fertilizer and $\mathrm{ZnONPs}$ and their seed application techniques, i.e., as seed priming and coating treatments for 
the vegetative growth, and yield attributes besides soil chemical and microbiological characteristics in maize (Zea mays variety J-1006) crop grown under field conditions.

\section{Materials and Methods}

Analytical-grade chemicals were purchased from Himedia Laboratories, Mumbai, India. Zinc oxide nanoparticles were prepared through the wet chemistry technique as described in Section 2.1.

\subsection{Synthesis and Characterization of $\mathrm{ZnONPS}$}

The $\mathrm{ZnONPs}$ were synthesized through the wet chemistry technique [23]. Zinc acetate dihydrate $\left(\mathrm{Zn}\left(\mathrm{CH}_{3} \mathrm{COO}\right)_{2} \cdot 2 \mathrm{H}_{2} \mathrm{O}, 2\right.$ moles) and sodium hydroxide $(\mathrm{NaOH}, 1$ mole) were dissolved in isopropyl alcohol $(100 \mathrm{~mL})$ by stirring at room temperature for $30 \mathrm{~min}$. The solution was stirred again for several hours at room temperature after the addition of a few drops of ammonia solution to obtain alkaline $\mathrm{pH}$. The solution was then filtered, and the residue was washed with distilled water. The residue (gel) was dried at $50{ }^{\circ} \mathrm{C}$ and later was calcinated at $200^{\circ} \mathrm{C}$ in a muffle furnace to generate the ZnONPs. These ZnONPs were characterized for morphological features (size dimensions and shape) through transmission (model H-7650, Hitachi, Tokyo, Japan) and scanning (model S-3400N, Hitachi, Tokyo, Japan) electron microscopy. The characteristic light-matter interaction properties of the synthesized ZnONPs were characterized through UV-Visible spectroscopy (model SL 218, Elico, Hyderabad, India), Energy-dispersive X-ray spectroscopy, and Fourier TransformInfra Red spectroscopy (model Nicolet 6700, Thermo Scientific, Exton, PA, USA) analysis equipped with attenuated total reflectance (ATR) assembly.

\subsection{Seed Treatments for Field Study}

The stock solutions of concentration $100 \mu \mathrm{g} \mathrm{mL}^{-1}$ each were prepared by mixing bulk $\mathrm{ZnSO}_{4}$ salt $(10 \mathrm{mg})$ in deionized water $(100 \mathrm{~mL})$ while the stock suspensions for zinc oxide nanoparticles were prepared by suspending $10 \mathrm{mg}$ of dried powder ZnONPs in $100 \mathrm{~mL}$ of deionized water. Three different working concentrations of 0,20 , and $40 \mathrm{mg} \mathrm{L}^{-1}$ were prepared from both the $\mathrm{ZnONPs}$ suspension and $\mathrm{ZnSO}_{4}$ stock solution. The prepared ZnONPs suspensions were sonicated at $25^{\circ} \mathrm{C}$ for $20 \mathrm{~min}$ to allow the formation of uniform suspension and to prevent agglomeration of the nanoparticles. The prepared $\mathrm{ZnONPs}$ suspensions $/ \mathrm{ZnSO}_{4}$ solutions were used for the seed priming treatment by incubating these $(0.1 \mathrm{~mL}$ per seed) with the maize seeds for $30 \mathrm{~min}$. Before treatment with the ZnONPs suspensions or $\mathrm{ZnSO}_{4}$ solutions, the maize seed surface was disinfected by treatment with $2 \%$ sodium hypochlorite $(\mathrm{NaOCl})$ solution for $2 \mathrm{~min}$, followed by thorough rinsing with autoclaved deionized water. The seed coating treatment involved the preparation of the starch solution. Soluble corn starch $(1.5 \% w / v)$ and glycerol $(1.0 \% w / v)$ as plasticizer were added to a minimum volume of deionized water and heated at $40{ }^{\circ} \mathrm{C}$ to gelatinize the starch The zinc suspensions or solutions were then mixed with the gelatinized polymer and added to the maize seeds (at the rate of $10 \mu \mathrm{L}$ per seed). The nano-zinc oxide dispersions or bulk salt solutions and their starch polymer solutions were placed on a rocking shaker for $30 \mathrm{~min}$ with occasional handshaking to ensure even treatment of all the seeds. Furthermore, the primed and coated seeds were placed on filter paper and allowed to air dry. The treated seeds were manually sown in the field at a row spacing of $70 \mathrm{~cm}$ and plant-to-plant distance of $20 \mathrm{~cm}$ in the third week of June 2019. The crop was maintained as per the recommended practices for the cultivation of the maize crop. On harvesting, the vegetative growth and yield attributing traits of the crop were evaluated.

\subsection{Zinc Source Seed Treatment Effect on Vegetative Growth Parameters of Fodder Maize}

2.3.1. Vegetative, Photosynthetic, and Yield Parameters

The vegetative growth parameters such as number of plants per plot, number of leaves per plant, plant height, and ear height were observed at 60 DAS. The total chlorophyll content, an indicator of the photosynthetic performance was measured with the help of a 
SPAD photometer (SPAD-502, Soil Plant Analysis Development (SPAD) Section, Minolta Camera Co, Osaka, Japan) at 30 and 60 DAS. The total chlorophyll and carotenoid contents ( $\mathrm{mg} \mathrm{g}^{-1}$ leaf fresh weight) of the leaves sampled at 30 and 60 DAS were also estimated through the $80 \%$ acetone extraction method [24]. Yield attributing characteristics, i.e., number of internodes per plant and plant biomass, and total stover yield was determined at 60 DAS. The yield data were represented in $\mathrm{kg} \mathrm{ha}^{-1}$.

\subsubsection{Plant Nutrient Status}

The shoot and root samples were obtained at 60 DAS and were kept in the oven at $65 \pm 2{ }^{\circ} \mathrm{C}$ for drying until the moisture was removed and constant weights were obtained. Thereafter, the plant samples were analyzed for N, P, K, and Zn nutrient contents. Nitrogen was determined by Kjeldhal's method by digesting shoot and root samples with $10 \mathrm{~mL}$ of concentrated sulfuric acid in the presence of a digestion mixture. To measure the phosphorous and potassium contents of the shoot and root samples, the samples were wet digested in $\mathrm{HNO}_{3}$ and $\mathrm{HClO}_{4}$ acid mixture (ratio 4:1). The vanadomolybdate phosphorus yellow color method was used to calculate the phosphorous content in the nitric acid system. The potassium content was determined using the flame photometer method. For estimation of the zinc $(\mathrm{Zn})$ content, the oven-dried shoot and root samples were wet digested in $15 \mathrm{~mL}$ di-acid mixture of $\mathrm{HNO}_{3}$ and $\mathrm{HClO}_{4}(3: 1)$, and thereafter these were analyzed on an Atomic Absorption Spectroscope (AAS) as described by Lindsay and Norvell [25].

\subsubsection{Plant Quality Parameters}

The fodder quality indicators, the neutral detergent fiber (NDF), and acid detergent fiber (ADF) were determined by the method of Goering and Van Soest [26]. Briefly, this involved placing one gram of the dried shoot sample in a condenser-fitted round bottom flask. The NDF was estimated by using the neutral detergent solution while the ADF was analyzed through the acid detergent solution (Cetyl trimethyl ammonium bromide (CTAB). Thereafter, decaline $(2 \mathrm{~mL})$ and sodium sulphite $(0.5 \mathrm{~g})$ were added. The contents were boiled for 5 to $10 \mathrm{~min}$ and then gradually refluxed for $1 \mathrm{~h}$. The refluxed samples were transferred to a pre-weighed crucible fitted onto the filtering apparatus. It was then rinsed with hot water, followed by acetone, and dried at $105^{\circ} \mathrm{C}$ for $12 \mathrm{~h}$, and weighed. The residue dried weights were recorded as the NDF and ADF percentages. The difference was recorded as insoluble hemicellulose between NDF and ADF.

\subsubsection{Soil Nutrient and Microbiological Status}

The soil macronutrient $(\mathrm{N}, \mathrm{P}$, and $\mathrm{K}$ ) and zinc contents were determined at 30 and 60 DAS. To determine the soil macronutrient contents, the available nitrogen (N) was estimated through the alkaline permanganate method, and available phosphorous (P) by reduction of ascorbic acid [27]. Available potassium (K) was estimated through a flame photometer using a neutral ammonium acetate extractant. The micronutrient such as zinc (Zn) content was extracted by the diethylenetriaminepentaacetic acid (DTPA) method and estimated on an AAS as explained by Lindsay and Norvell [25]. The soil physical parameters are depicted in Table 1.

Table 1. Physical and chemical characteristics of the soil sampled from the experimental site.

\begin{tabular}{ll}
\hline Soil Parameter & Value \\
\hline Type & Sandy loam \\
pH & 8.56 \\
EC $\left(\mathrm{dS} \mathrm{m}^{-\mathbf{1}}\right)$ & $\mathbf{0 . 4}$ \\
OC $(\%)$ & 0.52 \\
Clay $(\%)$ & 12 \\
Sand $(\%)$ & 70 \\
Silt $(\%)$ & 18 \\
\hline
\end{tabular}

EC- electrical conductivity; OC- Organic carbon. 
The viable cell count of the rhizospheric soil was enumerated by the dilution spread plating technique. The total aerobic bacteria, total fungi, actinobacteria, and pseudomonad viable cell counts were determined at regular intervals of 30 and 60 DAS of crop on nutrient agar, potato dextrose agar, actinomycetes agar, and King's B agar media, respectively. The soil dehydrogenase enzyme activity was assayed according to Casida et al. [28]. At the same time, the soil alkaline and acid phosphatase activities for the same soil samples were also estimated [29].

\subsubsection{Statistical Analysis}

The experiment was laid out in a factorial randomized block design for ten treatments with three replications. The analysis of variance (ANOVA) was performed using generalized linear model procedure (PROC GLM statement) in SAS Software (version 9.3, SAS Institute Inc., Cary, NC, USA). The mean comparison for various vegetative growth, soil nutrient and microbiological, yield attribution, and quality parameters was performed by utilizing the Fisher's protected Least Significant Difference (LSD) test at $p \leq 0.05$. The Principal Component Analysis (PCA based on Pearson correlation) of the yield and quality characteristics, soil microbial viable counts and enzymatic activities and shoot and soil nutrient parameters was performed using multivariate analysis tab in Origin software (version 9.0, USA). The PCA biplots were prepared in Origin (version 9.0, USA) software which indicated the relative associations and impact of different parameters with each other.

\section{Results}

\subsection{Characterization of the Prepared $\mathrm{ZnO} N \mathrm{Ss}_{\mathrm{s}}$}

The ZnONPs synthesized through the wet chemistry technique exhibited particles with quasi-spherical to irregular shapes, well-defined margins, and predominant size dimensions ranging from 10 to $40 \mathrm{~nm}$ (Figure 1a,b) though larger particles of size 60 to $120 \mathrm{~nm}$ were also observed. The scanning electron microscopy analysis depicted the average particle aggregate size of $<500 \mathrm{~nm}$ (Figure 2a). The occurrence of the Zn element on the surface of the prepared ZnONPs was uniformly distributed besides showing fingerprint $\mathrm{X}$-ray peaks at 1.0 and $8.601 \mathrm{keV}$, respectively, representing the $\mathrm{L}$ and $\mathrm{K} \alpha$ lines for the $\mathrm{Zn}$ element (Figure 2b). The X-ray map of the surface of the ZnONPs indicated the uniform occurrence of the $\mathrm{Zn}$ signals (Figure 2c). The quantitative table (Figure $2 \mathrm{~d}$ ) depicted the presence of zinc and oxygen elements. The carbon signals are from the sticky carbon tape used to load the sample on the stub while the nitrogen and chlorine signal are from the precursors/chemicals utilized for the synthesis of the ZnONPs.
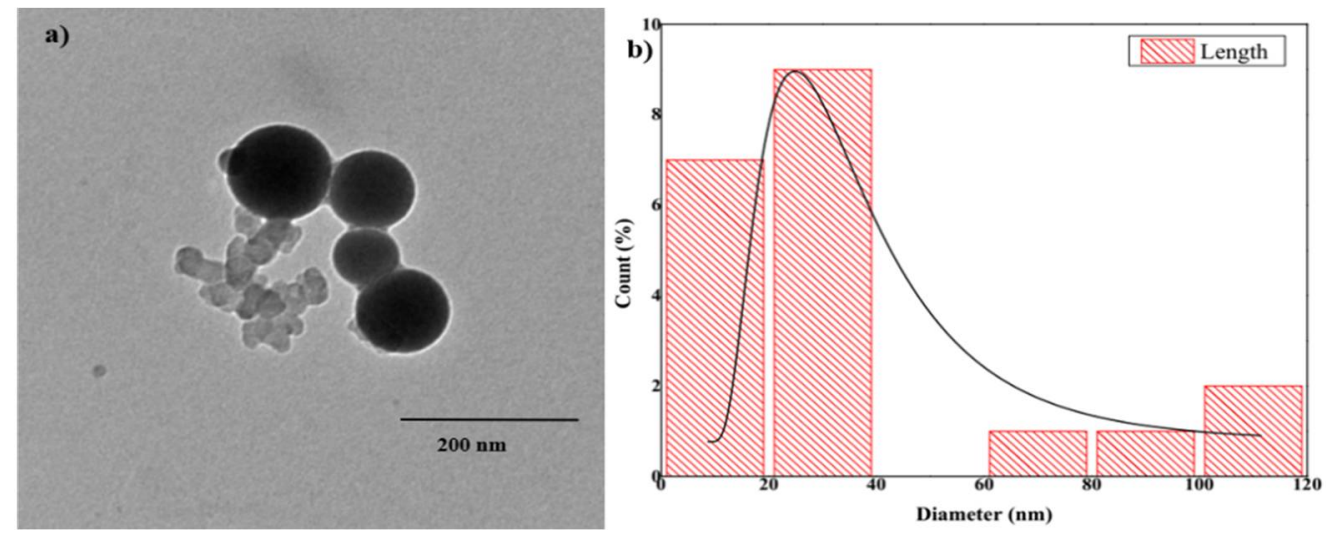

Figure 1. Transmission electron micrographs of zinc oxide nanoparticles showing (a) sphericalshaped zinc oxide nanoparticles (ZnONPs), (b) size distribution curve. 

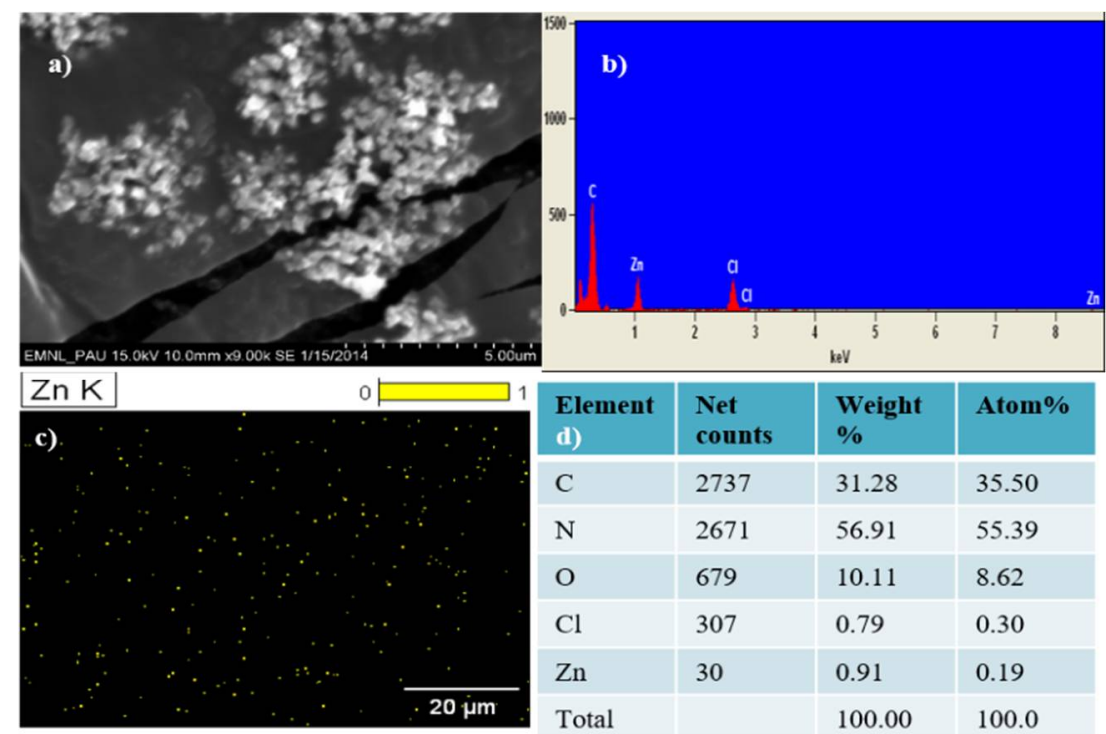

\begin{tabular}{|l|l|l|l|}
\hline $\begin{array}{l}\text { Element } \\
\text { d) }\end{array}$ & $\begin{array}{l}\text { Net } \\
\text { counts }\end{array}$ & $\begin{array}{l}\text { Weight } \\
\%\end{array}$ & Atom\% \\
\hline $\mathrm{C}$ & 2737 & 31.28 & 35.50 \\
\hline $\mathrm{N}$ & 2671 & 56.91 & 55.39 \\
\hline $\mathrm{O}$ & 679 & 10.11 & 8.62 \\
\hline $\mathrm{Cl}$ & 307 & 0.79 & 0.30 \\
\hline $\mathrm{Zn}$ & 30 & 0.91 & 0.19 \\
\hline Total & & 100.00 & 100.0 \\
\hline
\end{tabular}

Figure 2. Scanning electron micrograph of ZnONPs depicting (a) the smooth-surfaced aggregates, (b) SEM-EDS spectra of the prepared ZnONPs showing characteristic peaks for the Zn element, (c) Xray map of ZnONPs showing the signals for the uniformly distributed $\mathrm{Zn}$ element, (d) quantitative table exhibiting the occurrence of $\%$ atom and \% weight $\mathrm{Zn}$ element.

The UV absorption peak for the prepared ZnONPs appeared as a single and sharp peak at $210 \mathrm{~nm}$ wavelength (Figure 3a) indicating the monodispersed nature of the nanoparticle dispersion. It also indicated that most of the particles in the aqueous dispersion had uniform nano-scale dimensions. The chemical functional group diversity of the prepared ZnONPs as elucidated through Fourier Transform Infrared Spectroscopy (FT-IRS) analysis showed the shift in absorption peak at 3078.6 to $3085.4 \mathrm{~cm}^{-1}$ wavenumbers indicating the stretching vibrations of the $\mathrm{C}-\mathrm{H}$ group derived from either the precursor salt (zinc acetate) or the isopropyl alcohol used for the synthesis of the nanoparticles (Figure 3b).
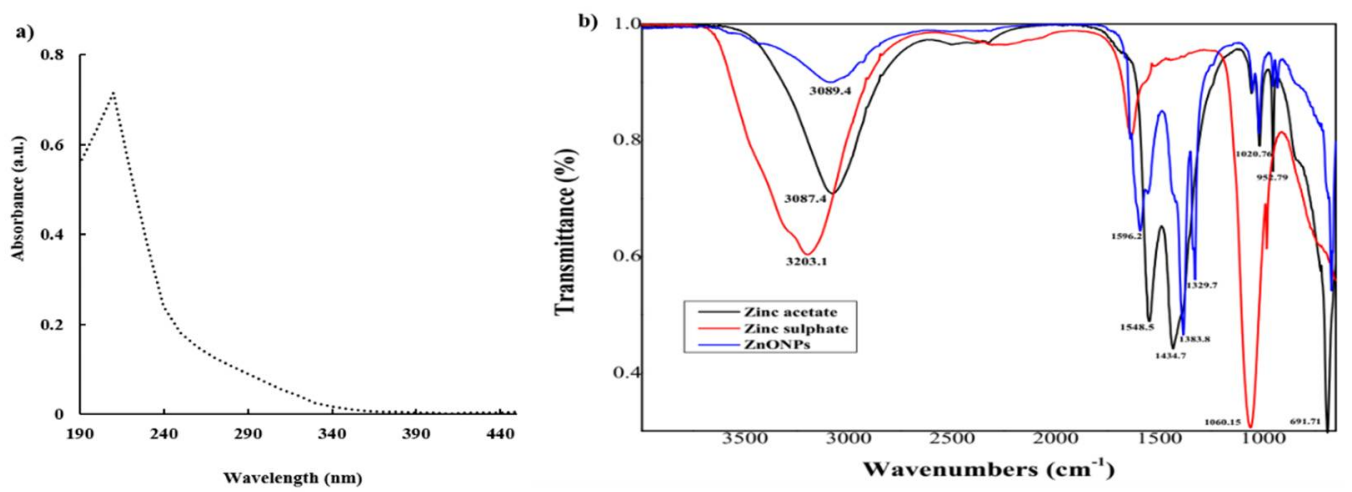

Figure 3. Spectroscopy characterization of ZnONPs. (a) UV-Vis absorption peak of ZnONPs, (b) FT-IR spectra of ZnONPs and the salt precursors showing variation in the chemical functional groups on formation of ZnONPs from the precursor salt.

Furthermore, a shift in absorption peak at 1638.5 to $1594.4 \mathrm{~cm}^{-1}$ wavenumbers in the FTIR spectra of the synthesized ZnONPs indicates stretching vibrations of the $\mathrm{C}=\mathrm{C}$ group, while the symmetric and asymmetric stretching vibrations of the $\mathrm{O}-\mathrm{C}-\mathrm{O}$ bond of carbonate (absorbed) anion can be observed from peaks at 1329/1386, and $1549 \mathrm{~cm}^{-1}$. The lattice vibration peaks for absorbed carbonate can also be observed at $1052 \mathrm{~cm}^{-1}$. The peaks present in the 1435 to $1300 \mathrm{~cm}^{-1}$ wavenumber range (ZnONP: $1386,1329 \mathrm{~cm}^{-1}$, and zinc acetate: $1435 \mathrm{~cm}^{-1}$ ) represent the $\mathrm{CH}_{3}$ bond bending vibrations. Likewise, another shift in peak from 1058 to $1020 \mathrm{~cm}^{-1}$ wavenumber region may be attributed to stretching vibrations 
of the $\mathrm{C}=\mathrm{O}$ functional group. Absorption peaks between 1100 and $900 \mathrm{~cm}^{-1}$ in all the three spectra can be associated with $\mathrm{Zn}-\mathrm{OH}$ vibrations particularly the peaks at 1018.5 and $1020.7 \mathrm{~cm}^{-1}$ in FTIR spectra of zinc acetate precursor salt and ZnONPs, respectively indicate the corresponding $\mathrm{Zn}-\mathrm{O}$ bond vibrations. The band at $690.4 \mathrm{~cm}^{-1}$ in the FT-IR spectra of the zinc acetate precursor salt can be ascribed to the scissoring vibration of the acetate anion. This peak was abolished in the ZnONPs spectra with the emergence of a new peak at $671.5 \mathrm{~cm}^{-1}$ representing the $\mathrm{Zn}-\mathrm{O}$ bond stretching vibrations.

\subsection{Vegetative and Photosynthetic Parameters}

The plant stand is an important parameter that affects the growth and yield responses in maize. The analysis of variance table for these traits indicated significant variation for the Zn-source concentrations only for the vegetative traits with only leaf number trait which exhibited dual interaction of treatment $\times$ concentration (Supplementary Tables S1 and S2). The number of plants per plot was not affected by priming or coating seed treatments in fodder maize var. J-1006. However, this trait exhibited significant improvement in ZnONPs treatment $\left(20 \mathrm{mg} \mathrm{L}^{-1}\right.$ ) compared to bulk $\mathrm{ZnSO}_{4}$ and control treatments (Table 2). Seed coating treatment improved the plant height compared to the priming treatment. A similar trend for the concentration of the Zn-source was observed with ZnONPs $\left(20 \mathrm{mg} \mathrm{L}^{-1}\right)$ exhibiting a significant increase in the plant height compared to bulk $\mathrm{ZnSO}_{4}$ and control treatments. Numerically higher shoot and significantly higher root fresh weight at harvest were recorded in seed coating treatment as compared to no polymer treatment. Additionally, the highest mean shoot and fresh root weights were observed in $\mathrm{ZnONPs}\left(20 \mathrm{mg} \mathrm{L}^{-1}\right)$ treatment as compared to the control and ZnONPs $\left(40 \mathrm{mg} \mathrm{L}^{-1}\right)$ treatments, respectively. The leaf number was significantly higher in starch polymer seed coating treatments compared to priming treatments. Among the Zn sources, the ZnONPs treatment (both at 20 and $40 \mathrm{mg} \mathrm{L}^{-1}$ concentrations) recorded the highest leaf number as compared to bulk $\mathrm{ZnSO}_{4}$ and control treatments (Table 2).

Table 2. Effect of seed treatments with different concentrations of ZnONPs on vegetative and yield attributing parameters of fodder maize crop (variety J-1006) grown under field conditions.

\begin{tabular}{|c|c|c|c|c|c|c|c|c|}
\hline Treatments & & $\begin{array}{l}\text { No. of } \\
\text { Plants }\end{array}$ & $\begin{array}{l}\text { Plant } \\
\text { Height } \\
\text { (cm) }\end{array}$ & $\begin{array}{c}\text { Leaf } \\
\text { Number }\end{array}$ & $\begin{array}{c}\text { No. of } \\
\text { Internode }\end{array}$ & $\begin{array}{c}\text { Total Stover } \\
\text { Yield (Quintal } \\
\text { ha }^{-1} \text { ) }\end{array}$ & $\begin{array}{c}\text { Mean Fresh } \\
\text { Shoot wt. } \\
(\mathbf{k g})\end{array}$ & $\begin{array}{c}\text { Mean Root } \\
\text { Fresh wt. } \\
\text { (g) }\end{array}$ \\
\hline Seed & Priming & $34.0 \mathrm{a}$ & $222.13 \mathrm{a}$ & $10.0 \mathrm{~b}$ & $7.0 \mathrm{a}$ & $37.02 \mathrm{a}$ & $2.036 \mathrm{a}$ & $290.67 \mathrm{~b}$ \\
\hline Treatment & Coating & $33.0 \mathrm{a}$ & $224.20 \mathrm{a}$ & $11.0 \mathrm{a}$ & $8.0 \mathrm{a}$ & $36.72 \mathrm{a}$ & $2.108 \mathrm{a}$ & $340.87 \mathrm{a}$ \\
\hline \multirow{5}{*}{$\begin{array}{l}\text { Zn source } \\
\left(\mathrm{mg} \mathrm{L}^{-1}\right)\end{array}$} & 0 & $26.0 \mathrm{~b}$ & $210.00 \mathrm{c}$ & $8.0 \mathrm{c}$ & $7.00 \mathrm{c}$ & $31.07 \mathrm{~b}$ & $1.810 \mathrm{c}$ & $244.00 \mathrm{c}$ \\
\hline & $\mathrm{ZnSO}_{4} 20$ & $29.0 \mathrm{~b}$ & $207.66 \mathrm{c}$ & $10.0 \mathrm{~b}$ & $7.50 \mathrm{bc}$ & $32.23 \mathrm{~b}$ & $1.860 \mathrm{bc}$ & $246.67 c$ \\
\hline & $\mathrm{ZnSO}_{4} 40$ & $37.0 \mathrm{a}$ & $219.33 b$ & $11.0 \mathrm{~b}$ & $7.83 \mathrm{~b}$ & $38.58 \mathrm{a}$ & $1.730 \mathrm{c}$ & $280.33 c$ \\
\hline & ZnONPs 20 & $38.0 \mathrm{a}$ & $241.83 \mathrm{a}$ & $12.0 \mathrm{a}$ & $8.83 \mathrm{a}$ & $43.45 \mathrm{a}$ & $2.620 \mathrm{a}$ & $437.50 \mathrm{a}$ \\
\hline & ZnONPs 40 & $37.0 \mathrm{a}$ & $237.00 \mathrm{a}$ & $12.0 \mathrm{a}$ & $9.50 \mathrm{a}$ & $39.02 \mathrm{a}$ & $2.310 \mathrm{ab}$ & $370.33 \mathrm{~b}$ \\
\hline
\end{tabular}

Means within the sub-factor followed by the same letter in a column are not significantly different at $p \leq 0.05$ according to pair-wise comparison of least square means.

The analysis of variance for the photosynthetic pigments indicated the significant effect of DAS, seed treatment and Zn-source concentrations individually and their dual and triple interactions (Supplementary Tables S3 and S4). The chlorophyll fluorescence as estimated through the SPAD meter was recorded to be highest at 60 DAS. A concentrationdependent enhancement in SPAD readings was recorded for ZnONPs with the highest values appearing for $\mathrm{ZnONPs}\left(40 \mathrm{mg} \mathrm{L}^{-1}\right.$ ) treatment (Table 3). However, the total chlorophyll and total carotenoid contents as estimated through the acetone extraction method followed a similar trend of higher values at 60 DAS and in ZnONPs $\left(20 \mathrm{mg} \mathrm{L}^{-1}\right)$ treatment. The effect of seed coating treatment on total chlorophyll content was significantly higher compared to priming treatment though the total carotenoid content remained the same among these seed treatments. 
Table 3. Effect of application of different concentrations of ZnONPs on chlorophyll fluorescence measured with Soil Plant Analysis Development (SPAD) meter and total chlorophyll and carotenoid contents in maize var. J-1006.

\begin{tabular}{|c|c|c|c|c|}
\hline \multicolumn{2}{|c|}{ Source of Variation } & \multirow{2}{*}{$\begin{array}{c}\text { Chlorophyll } \\
\text { Content (SPAD } \\
\text { Readings) }\end{array}$} & \multirow{2}{*}{$\begin{array}{c}\begin{array}{c}\text { Total } \\
\text { Chlorophyll } \\
\left(\mathbf{m g ~ g}^{-1} \text { Fresh }\right. \\
\text { Leaf Tissue) }\end{array} \\
8.59 \mathrm{~b}\end{array}$} & \multirow{2}{*}{$\begin{array}{c}\begin{array}{c}\text { Total } \\
\text { Carotenoids } \\
\left(\mathbf{m g ~ g}^{-1} \text { Fresh }\right. \\
\text { Leaf Tissue })\end{array} \\
0.36 \mathrm{~b}\end{array}$} \\
\hline Days after & 30 & & & \\
\hline sowing (DAS) & 60 & 46.70 a & $10.22 \mathrm{a}$ & $0.57 \mathrm{a}$ \\
\hline \multirow{2}{*}{ Seed treatment } & Priming & $45.64 \mathrm{~b}$ & $9.05 \mathrm{~b}$ & 0.468 a \\
\hline & Coating & $49.14 \mathrm{a}$ & $9.76 \mathrm{a}$ & $0.464 \mathrm{a}$ \\
\hline \multirow{5}{*}{$\begin{array}{l}\text { Zn source } \\
\left(\mathrm{mg} \mathrm{L}^{-1}\right)\end{array}$} & 0 & $44.60 \mathrm{c}$ & $6.24 \mathrm{e}$ & $0.443 \mathrm{bc}$ \\
\hline & $\mathrm{ZnSO}_{4} 20$ & $44.85 \mathrm{c}$ & $9.63 c$ & $0.463 \mathrm{~b}$ \\
\hline & $\mathrm{ZnSO}_{4} 40$ & $48.02 \mathrm{ab}$ & $8.83 \mathrm{~d}$ & $0.456 \mathrm{bc}$ \\
\hline & ZnONPs 20 & $47.84 \mathrm{ab}$ & $11.67 \mathrm{a}$ & $0.497 \mathrm{a}$ \\
\hline & ZnONPs 40 & $48.72 \mathrm{a}$ & $10.66 \mathrm{~b}$ & $0.470 \mathrm{~b}$ \\
\hline
\end{tabular}

Means within the sub-factor followed by the same letter in a column are not significantly different at $p \leq 0.05$ according to pair-wise comparison of least square means.

\subsection{Yield and Plant Nutrient Status}

The $\mathrm{Zn}$-source concentrations exhibited the significant effect on the yield and attributing traits (Supplementary Table S1). The internode number in the fodder maize is a potential indicator of improved growth and biomass. Seed coating treatment significantly enhanced the internode number. Additionally, ZnONPs treatment $\left(20 \mathrm{mg} \mathrm{L}^{-1}\right)$ significantly improved the internode number compared to bulk $\mathrm{ZnSO}_{4}\left(20\right.$ and $\left.40 \mathrm{mg} \mathrm{L}^{-1}\right)$ and control treatments (Table 2). However, both seed priming and coating treatments exhibited statistically on par performance for the total stover yield though ZnONPs $\left(20 \mathrm{mg} \mathrm{L}^{-1}\right)$ showed the highest stover yield (Table 2).

The type of plant tissue, seed treatments and $\mathrm{Zn}$-source concentrations and their dual and triple interactions significantly altered the plant nutrient content including N, P, K and $\mathrm{Zn}$ contents (Supplementary Tables S5 and S6). The application of $\mathrm{ZnONPs}$ and bulk $\mathrm{ZnSO}_{4}$ resulted in an increase in NPK and zinc content in the shoot and root of fodder maize var. J-1006 at 60 DAS. Seed coating treatments exhibited significantly maximum N, P, K, and Zn contents as compared to priming treatments. Among the zinc source concentrations, the maximum N, P, and K contents were recorded for ZnONPs (at $40 \mathrm{mg} \mathrm{L}^{-1}$ ) treatment. However, maximum $\mathrm{Zn}$ content was recorded for $20 \mathrm{mg} \mathrm{L}^{-1} \mathrm{ZnONPs}$ treatment with the bulk $\mathrm{ZnSO}_{4}$ (at 20 and $40 \mathrm{mg} \mathrm{L}^{-1}$ ) treatments exhibiting relatively lower Zn contents (Table 4).

Table 4. Effect of seed treatments with different concentrations of ZnONPs on plant nutrient status of fodder maize (variety J-1006) grown under field conditions.

\begin{tabular}{|c|c|c|c|c|c|}
\hline \multicolumn{2}{|c|}{ Source of Variation } & \multirow{2}{*}{$\begin{array}{l}\mathbf{N}(\mathbf{\%}) \\
0.833 \mathrm{~b}\end{array}$} & \multirow{2}{*}{$\frac{\mathbf{K}(\mathbf{\%})}{6.707 \mathrm{~b}}$} & \multirow{2}{*}{$\frac{\mathbf{P}(\%)}{1.208 \mathrm{~b}}$} & \multirow{2}{*}{$\frac{\mathbf{Z n}\left(\mathbf{m g ~ k g} \mathbf{~}^{-\mathbf{1}}\right)}{3.27 \mathrm{~b}}$} \\
\hline & Shoot & & & & \\
\hline Plant tissue & Root & $1.186 \mathrm{a}$ & $7.38 \mathrm{a}$ & $1.229 \mathrm{a}$ & $3.69 \mathrm{a}$ \\
\hline Seed & Priming & $0.898 \mathrm{~b}$ & $6.586 \mathrm{~b}$ & $1.155 \mathrm{~b}$ & $1.60 \mathrm{~b}$ \\
\hline Treatment & Coating & $1.120 \mathrm{a}$ & $8.130 \mathrm{a}$ & $1.237 \mathrm{a}$ & $3.77 \mathrm{a}$ \\
\hline \multirow{5}{*}{$\begin{array}{l}\text { Zn source } \\
\left(\mathrm{mg} \mathrm{L}^{-1}\right)\end{array}$} & 0 & $0.703 \mathrm{e}$ & $4.063 \mathrm{e}$ & $1.076 \mathrm{e}$ & $1.158 \mathrm{e}$ \\
\hline & $\mathrm{ZnSO}_{4} 20$ & $0.923 \mathrm{~d}$ & $6.70 \mathrm{~d}$ & $1.157 \mathrm{~d}$ & $2.456 \mathrm{c}$ \\
\hline & $\mathrm{ZnSO}_{4} 40$ & $1.032 \mathrm{c}$ & $7.94 \mathrm{c}$ & $1.201 \mathrm{c}$ & $2.412 \mathrm{~d}$ \\
\hline & ZnONPs 20 & $1.137 \mathrm{~b}$ & $8.87 \mathrm{~b}$ & $1.250 \mathrm{~b}$ & $4.167 \mathrm{a}$ \\
\hline & ZnONPs 40 & $1.251 \mathrm{a}$ & $9.20 \mathrm{a}$ & $1.297 \mathrm{a}$ & $3.275 \mathrm{~b}$ \\
\hline
\end{tabular}

Means within the sub-factor followed by the same letter in a column are not significantly different at $p \leq 0.05$ according to pair-wise comparison of least square means. 


\subsection{Plant Quality Parameters}

Both the seed treatment and Zn-source concentration besides their interactions had significant effect on the plant quality parameters of fodder maize crop (Supplementary Tables S1 and S2). The seed priming and coating treatments with different concentrations of $\mathrm{Zn}$ sources affected the fiber qualities (neutral detergent fiber (NDF), acid detergent fiber (ADF), hemicellulose, and cellulose contents) of the harvested fodder maize (var. J-1006) plants. An enhanced NDF and hemicellulose content was observed in the seed priming treatments while the seed coating treatments increased the ADF and cellulose content (Table 5). The application of ZnONPs (at $40 \mathrm{mg} \mathrm{L}^{-1}$ concentration) exhibited significantly highest NDF and cellulose content as compared to ZnONPs treatment (at $20 \mathrm{mg} \mathrm{L}^{-1}$ ) as compared to bulk $\mathrm{ZnSO}_{4}\left(20\right.$ and $40 \mathrm{mg} \mathrm{L}^{-1}$ ) and control treatments.

Table 5. Effect of time duration (DAS) and seed treatment with various concentrations of ZnONPs applied on fiber content in fodder maize crop (variety J-1006) grown under field conditions.

\begin{tabular}{|c|c|c|c|c|c|}
\hline \multicolumn{2}{|c|}{ Source of Variation } & \multirow{2}{*}{$\frac{\text { NDF (\%) }}{62.42 a}$} & \multirow{2}{*}{$\begin{array}{c}\text { ADF (\%) } \\
38.22 \mathrm{~b}\end{array}$} & \multirow{2}{*}{$\begin{array}{c}\text { Hemicellulose (\%) } \\
24.18 \mathrm{a}\end{array}$} & \multirow{2}{*}{$\begin{array}{c}\text { Cellulose (\%) } \\
29.00 \mathrm{~b}\end{array}$} \\
\hline Seed & Priming & & & & \\
\hline Treatment & Coating & $60.60 \mathrm{a}$ & $40.20 \mathrm{a}$ & $20.90 \mathrm{~b}$ & 30.33 a \\
\hline \multirow{5}{*}{$\begin{array}{l}\text { Zn source } \\
\left(\mathrm{mg} \mathrm{L}^{-1}\right)\end{array}$} & 0 & $57.30 \mathrm{e}$ & $37.86 \mathrm{bc}$ & $19.43 \mathrm{~d}$ & $28.80 \mathrm{~b}$ \\
\hline & $\mathrm{ZnSO}_{4} 20$ & $59.80 \mathrm{~d}$ & $38.45 \mathrm{~b}$ & $21.35 c$ & $28.61 \mathrm{~b}$ \\
\hline & $\mathrm{ZnSO}_{4} 40$ & $62.05 c$ & $36.18 \mathrm{c}$ & $25.71 \mathrm{a}$ & $28.88 \mathrm{~b}$ \\
\hline & ZnONPs 20 & $63.16 \mathrm{~b}$ & $42.41 \mathrm{a}$ & $24.16 \mathrm{~b}$ & $30.76 \mathrm{a}$ \\
\hline & ZnONPs 40 & $65.23 \mathrm{a}$ & $41.13 \mathrm{a}$ & $22.03 c$ & $31.26 \mathrm{a}$ \\
\hline
\end{tabular}

Means within the sub-factor followed by the same letter in a column are not significantly different at $p \leq 0.05$ according to pair-wise comparison of least square means.

\subsection{Soil Nutrient Status and Microbial Parameters}

The soil nutrient status was significantly varied by DAS, seed treatments and the $\mathrm{Zn}$-source concentrations individually and due to interactive effects among the sources of variations (Supplementary Tables S7 and S8). A higher N, P, K, and Zn contents for soil sampled at 60 DAS was recorded (Table 6). Seed coating treatment exhibited significantly increased available soil $\mathrm{N}$ and $\mathrm{K}$ contents as compared to seed priming treatment. Meanwhile, among the Zn-source concentrations, significantly higher available soil N, and $\mathrm{P}, \mathrm{K}$, and $\mathrm{Zn}$ contents were recorded in ZnONPs treatments for 40 and $20 \mathrm{mg} \mathrm{L}^{-1}$ concentrations, respectively.

Table 6. Effect of time duration (DAS), and seed treatment with various concentrations of ZnONPs on soil nutrient content (N, P, K, and Zn) for fodder maize crop (variety J-1006) grown under field conditions.

\begin{tabular}{|c|c|c|c|c|c|}
\hline \multicolumn{2}{|c|}{ Source of Variation } & \multirow{2}{*}{$\begin{array}{c}\mathbf{N}\left(\mathbf{k g ~ h a}^{-\mathbf{1}}\right) \\
206.72 \mathrm{~b}\end{array}$} & \multirow{2}{*}{ 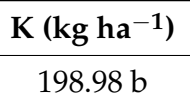 } & \multirow{2}{*}{ 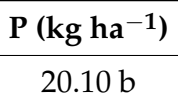 } & \multirow{2}{*}{$\frac{\mathrm{Zn}\left(\mathbf{m g ~ k g} \mathbf{~}^{-\mathbf{1}}\right)}{2.36 \mathrm{~b}}$} \\
\hline & 35 & & & & \\
\hline DAS & 60 & $216.53 a$ & $211.56 \mathrm{a}$ & $24.08 \mathrm{a}$ & $2.70 \mathrm{a}$ \\
\hline \multirow{2}{*}{ Seed Treatment } & Priming & $190.13 b$ & $199.54 \mathrm{~b}$ & $22.25 \mathrm{a}$ & $2.60 \mathrm{a}$ \\
\hline & Coating & $233.12 \mathrm{a}$ & $211.01 \mathrm{a}$ & $21.95 \mathrm{~b}$ & $2.46 \mathrm{~b}$ \\
\hline \multirow{5}{*}{$\begin{array}{l}\text { Zn source } \\
\left(\mathrm{mg} \mathrm{L}^{-1}\right)\end{array}$} & 0 & $152.80 \mathrm{e}$ & $190.89 \mathrm{~d}$ & $13.47 \mathrm{e}$ & $2.31 \mathrm{e}$ \\
\hline & $\mathrm{ZnSO}_{4} 20$ & $191.05 \mathrm{~d}$ & $199.54 \mathrm{c}$ & $18.62 \mathrm{~d}$ & $2.88 \mathrm{a}$ \\
\hline & $\mathrm{ZnSO}_{4} 40$ & $221.78 \mathrm{c}$ & $207.38 \mathrm{~b}$ & $20.07 c$ & $2.61 \mathrm{a}$ \\
\hline & ZnONPs 20 & 240.96 b & $214.61 \mathrm{a}$ & $27.25 \mathrm{~b}$ & $2.44 \mathrm{c}$ \\
\hline & ZnONPs 40 & $251.53 \mathrm{a}$ & $213.94 \mathrm{a}$ & $31.03 \mathrm{a}$ & $2.40 \mathrm{~d}$ \\
\hline
\end{tabular}

Means within the sub-factor followed by the same letter in a column are not significantly different at $p \leq 0.05$ according to pair-wise comparison of least square means.

The three sources of variation, i.e., DAS, seed treatments and Zn-source concentrations exhibited significant variations for the soil microbiological parameters individually, and as dual or triple interactions (Supplementary Tables S7 and S8). The maximum dehydrogenase $(1.26 \mu \mathrm{g}$ TPF formed/g of soil/h) and alkaline phosphatase activities $(1.048 \mu \mathrm{g}$ 
TPF formed/g of soil) were observed at 60 DAS which were statistically on par with enzyme activities at 35 DAS (Table 7). The high dehydrogenase activity (1.271 $\mu \mathrm{g}$ TPF formed/g of soil), acid phosphatase activity $(0.98660 \mu \mathrm{g}$ PNP formed/g of soil), and alkaline phosphatase activities (1.20 $\mu \mathrm{g}$ PNP formed/g of soil) were observed for starch polymer coating treatment as compared to no polymer treatment. The dehydrogenase (1.580 $\mu \mathrm{g}$ TPF formed/g of soil), acid phosphatase (1.077 $\mu \mathrm{g}$ PNP formed/g of soil/h), and alkaline phosphatase activities (1.292 $\mu \mathrm{g}$ TPF formed/g of soil) recorded for ZnONPs (at $40 \mathrm{mg} \mathrm{L}^{-1}$ ) were higher compared to bulk $\mathrm{ZnSO}_{4}$ and control treatments (Table 7).

Table 7. Effect of time duration (DAS), seed treatment with various concentrations of ZnONPs on soil enzyme activities in fodder maize crop (variety J-1006) grown under field conditions.

\begin{tabular}{|c|c|c|c|c|}
\hline \multirow{2}{*}{\multicolumn{2}{|c|}{ Source of Variation }} & \multirow{2}{*}{$\begin{array}{l}\text { Dehydrogenase Activity ( } \mu \mathrm{g} \\
\text { TPF Formed/g Soil/h) }\end{array}$} & \multicolumn{2}{|c|}{ Phosphatase Activity ( $\mu \mathrm{g}$ PNP/g of Soil) } \\
\hline & & & Acid & Alkaline \\
\hline \multirow{2}{*}{ DAS } & 35 & $1.2620 \mathrm{a}$ & $0.9035 \mathrm{a}$ & $0.8240 \mathrm{~b}$ \\
\hline & 60 & $1.2413 \mathrm{~b}$ & $0.8716 \mathrm{~b}$ & $1.0483 \mathrm{a}$ \\
\hline \multirow{2}{*}{ Seed Treatment } & Priming & $1.2323 \mathrm{~b}$ & $0.7886 \mathrm{~b}$ & $0.6660 \mathrm{~b}$ \\
\hline & Coating & $1.2710 \mathrm{a}$ & $0.9865 \mathrm{a}$ & $1.20633 \mathrm{a}$ \\
\hline \multirow{5}{*}{ Zn source $\left(\mathrm{mg} \mathrm{L}^{-1}\right)$} & 0 & $0.7325 \mathrm{e}$ & $0.5108 \mathrm{e}$ & $0.5108 \mathrm{e}$ \\
\hline & $\mathrm{ZnSO}_{4} 20$ & $1.1775 \mathrm{~d}$ & $0.8716 \mathrm{~d}$ & $0.8400 \mathrm{~d}$ \\
\hline & $\mathrm{ZnSO}_{4} 40$ & $1.2366 \mathrm{c}$ & $0.9430 \mathrm{c}$ & $0.9225 c$ \\
\hline & ZnONPs 20 & $1.5316 \mathrm{~b}$ & $1.0350 \mathrm{~b}$ & $1.1150 \mathrm{~b}$ \\
\hline & ZnONPs 40 & $1.5800 \mathrm{a}$ & $1.0775 \mathrm{a}$ & $1.2925 \mathrm{a}$ \\
\hline
\end{tabular}

Means within the sub-factor followed by the same letter in a column are not significantly different at $p \leq 0.05$ according to pair-wise comparison of least square means.

The highest count of soil microbes such as bacteria, fungi, pseudomonads, actinobacteria, and non-symbiotic N-fixer (Azotobacter sp.) was recorded at $60 \mathrm{DAS}$. Starch polymer coating treatment exhibited significantly increased microbial populations as compared to no polymer treatment (Table 8). Among the $\mathrm{Zn}$-source concentrations, $\mathrm{ZnONPs}$ (at $40 \mathrm{mg} \mathrm{L}^{-1}$ ) treatment exhibited a higher viable count of bacteria (2.99 $\log \mathrm{CFUg}^{-1}$ soil), fungus (1.97 $\log \mathrm{CFUg}^{-1}$ soil), pseudomonads (2.55 CFU g ${ }^{-1}$ soil), actinobacteria (2.54 $\log$ CFU g ${ }^{-1}$ of soil) and non-symbiotic $\mathrm{N}$-fixer count (3.40 $\log$ CFU g ${ }^{-1}$ of soil) as compared to bulk $\mathrm{ZnSO}_{4}$ and control treatments.

Table 8. Effects of time duration (DAS) and seed treatment with various concentrations of ZnONPs on viable cell count of microbes (log CFU g ${ }^{-1}$ soil) in rhizospheric soil of fodder maize crop (variety J-1006) grown under field conditions.

\begin{tabular}{|c|c|c|c|c|c|c|}
\hline \multicolumn{2}{|c|}{ Source of Variation } & \multirow{2}{*}{$\begin{array}{l}\text { Bacteria } \\
2.8760 \mathrm{~b}\end{array}$} & \multirow{2}{*}{$\begin{array}{c}\text { Fungi } \\
1.7333 \mathrm{~b}\end{array}$} & \multirow{2}{*}{$\begin{array}{c}\text { Pseudomonads } \\
2.3070 \mathrm{~b}\end{array}$} & \multirow{2}{*}{$\frac{\text { Actinobacteria }}{2.4063 \mathrm{~b}}$} & \multirow{2}{*}{$\begin{array}{c}\text { Non-Symbiotic N-Fixers } \\
3.1266 \mathrm{a}\end{array}$} \\
\hline DAS & 35 & & & & & \\
\hline & 60 & $2.9265 \mathrm{a}$ & $1.9368 \mathrm{a}$ & $2.4166 \mathrm{a}$ & $2.4883 \mathrm{a}$ & $3.1363 a$ \\
\hline \multirow[b]{2}{*}{ Seed Treatment } & Priming & $2.8281 \mathrm{~b}$ & $1.7856 \mathrm{~b}$ & $2.3556 \mathrm{~b}$ & $2.4080 \mathrm{~b}$ & $2.9723 \mathrm{~b}$ \\
\hline & Coating & $2.9744 \mathrm{a}$ & $1.8845 \mathrm{a}$ & $2.3680 \mathrm{a}$ & $2.4866 \mathrm{a}$ & $3.3006 \mathrm{a}$ \\
\hline \multirow{5}{*}{$\begin{array}{l}\text { Zn source }(\mathrm{mg} \\
\left.\mathrm{L}^{-1}\right)\end{array}$} & 0 & $2.6808 \mathrm{e}$ & $1.7225 \mathrm{c}$ & $2.2166 \mathrm{e}$ & $2.3058 \mathrm{e}$ & $2.5567 \mathrm{~b}$ \\
\hline & $\mathrm{ZnSO}_{4} 20$ & $2.9766 \mathrm{~b}$ & $1.7333 \mathrm{c}$ & $2.2933 \mathrm{~d}$ & $2.4350 \mathrm{~d}$ & $3.1900 \mathrm{a}$ \\
\hline & $\mathrm{ZnSO}_{4} 40$ & $2.0166 \mathrm{~d}$ & $1.7822 \mathrm{~b}$ & $2.3508 \mathrm{c}$ & $2.4608 \mathrm{c}$ & $3.2033 \mathrm{a}$ \\
\hline & ZnONPs 20 & $2.9366 \mathrm{c}$ & $1.9665 \mathrm{a}$ & $2.4891 \mathrm{a}$ & $2.4908 \mathrm{~b}$ & $3.3325 \mathrm{a}$ \\
\hline & ZnONPs 40 & $2.9954 \mathrm{a}$ & $1.9708 \mathrm{a}$ & $2.4591 \mathrm{~b}$ & $2.5441 \mathrm{a}$ & $3.4000 \mathrm{a}$ \\
\hline
\end{tabular}

Means within the sub-factor followed by the same letter in a column are not significantly different at $p \leq 0.05$ according to pair-wise comparison of least square means.

\subsection{Principal Component Analysis}

The PCA was performed to identify the extent of association among different plant vegetative, yield attributing, soil nutrient and microbiological parameters. The principal components (PC1 and PC2) explained the major proportion of the variance for growth and yield, photosynthetic pigments, soil and plant nutrient status and soil microbiological 
attributes which was $84.12,90.35,87.2$, and $87.56 \%$, respectively (Figure 4 ). The PCA results depicted a strong association among the number of leaves with stover yield and $\mathrm{NDF}$, shoot $\mathrm{N}$, soil $\mathrm{N}$ and shoot $\mathrm{K}$ traits and phosphatase enzyme activity with total soil actinobacterial population. Seed coating and priming with ZnONPs altered the maize vegetative traits, photosynthetic pigments, yield attributes, and soil and plant nutrient parameters (Figure $4 \mathrm{a}-\mathrm{c}$ ), while the seed priming and coating with ZnONPs and coating with bulk salt affected the soil microbiological properties (Figure $4 \mathrm{~d}$ ).
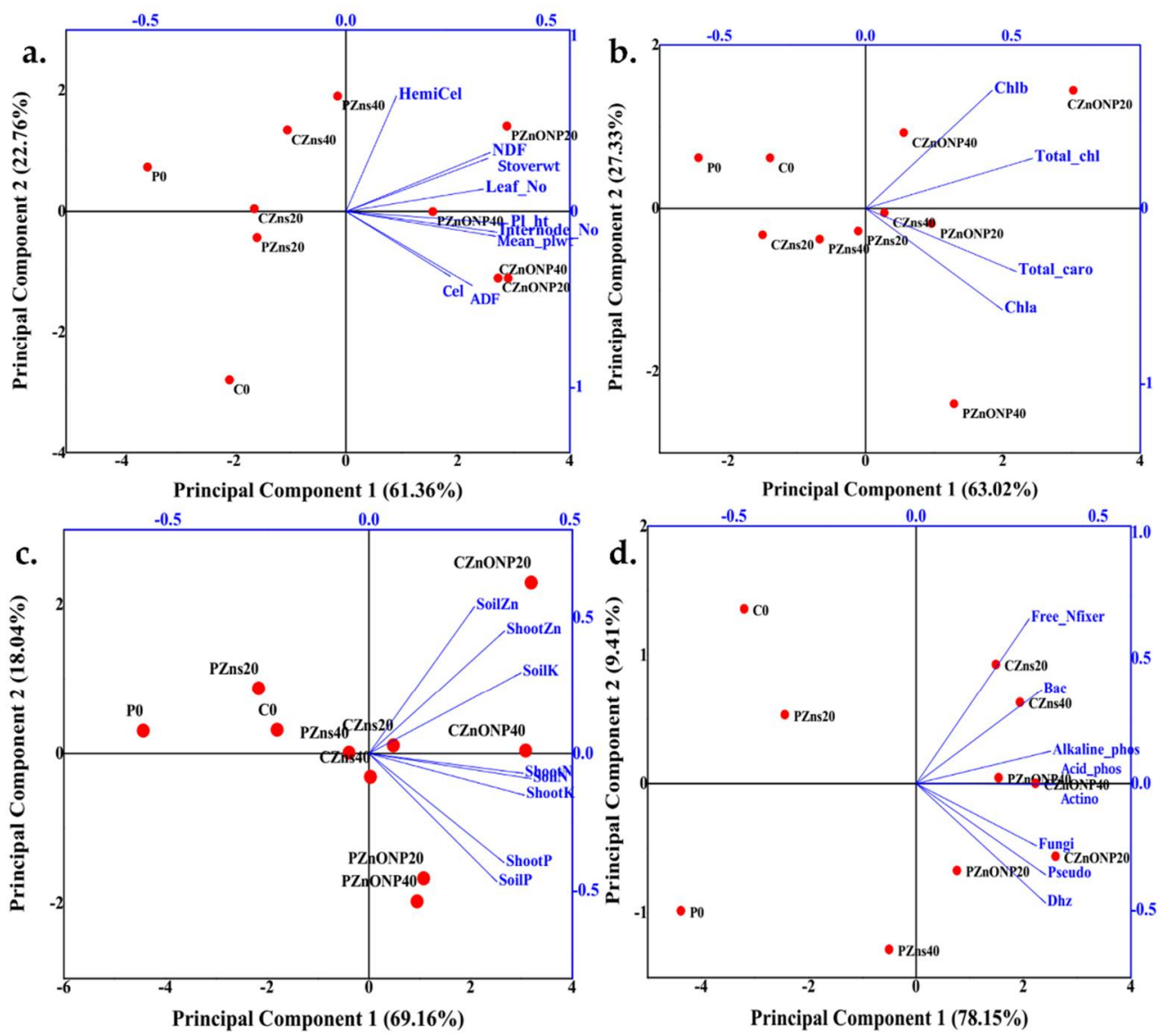

Figure 4. Principal component analysis of the maize vegetative and photosynthetic attributes, yield, nutrient status and soil microbiological parameters. (a) Vegetative and yield attributing traits, (b) photosynthetic pigments, (c) soil and plant shoot nutrient status, and (d) soil microbial viable counts and soil enzymatic characters.

\section{Discussion}

The synthesized ZnONPs on microscopy and spectroscopy characterizations exhibited peculiar properties indicating the nano-dimensions. The morphological characterization through SEM and TEM elucidated the occurrence of semi-spherical shape and small size $(10$ to $40 \mathrm{~nm})$ dimensions of the ZnONPs. Similar morphology of the synthesized ZnONPs has also been reported by Urbina et al. [6]. The SEM-EDS results corroborated the formation of ZnONPs as indicated through the presence of the characteristic X-ray peaks. The UV-Vis spectroscopy analysis of the ZnONPs showed a sharp absorbance peak at $210 \mathrm{~nm}$ wavelength. A similar UV absorbance peak at $202 \mathrm{~nm}$ has been reported for the sol-gel method-derived ZnONPs [23]. The single sharp peak is indicative of the nano-scale range and uniform size distribution of the $\mathrm{ZnO}$ particles in the aqueous suspension [6]. The Fourier Transform Infrared Spectroscopy (FT-IR) showed the occurrence of different functional groups derived from the solvent or other chemicals used for the preparation of the NPs to exist on the surface of the synthesized metal oxide nanoparticles. Metal oxides such as $\mathrm{ZnO}$ commonly exhibit characteristic IR absorption peaks in the fingerprint region 
of the FT-IR spectra of the prepared ZnONPs. Chemingui et al. [30] have observed a wide peak in the range of 3000 to $3500 \mathrm{~cm}^{-1}$ due to the $\mathrm{O}-\mathrm{H}$ bond vibration on FTIR analysis of the synthesized ZnONPs. The carbonate anions (O-C-O) symmetric and asymmetric vibrations besides the lattice vibrations have also been reported [31]. The three spectra contain the absorption peaks between 1100 and $900 \mathrm{~cm}^{-1}$ which can be ascribed to Zn$\mathrm{OH}$ vibrations [32] particularly the peaks at 1018.5 and $1020.7 \mathrm{~cm}^{-1}$ in FTIR spectra of zinc acetate precursor salt and $\mathrm{ZnONPs}$, respectively, indicate the corresponding $\mathrm{Zn}-\mathrm{O}$ bond vibrations.

Application of ZnONPs through seed priming and coating treatments enhanced the vegetative growth in field-grown fodder maize including improved plant height and number of plants per plot. This improvement may be attributed to the role of $\mathrm{Zn}$ in the production of tryptophan - the precursor of indole-3-acetic acid phytohormone [33]. ZnO nanoparticles can also modulate phytohormone biosynthesis of cytokinins and gibberellins which can lead to an increase in the number of internodes per plant [33]. Furthermore, enhanced cell elongation can lead to an increase in plant height in the early stages of plant development [34]. Similarly, Mahdieh et al. [35] have observed maximum enhancement in plant height in pinto bean (Phaseolus vulgaris L.) on seed treatment with ZnONPs (0.15\%). The photosynthetic pigments (total chlorophyll and carotenoids) were also enhanced on $\mathrm{ZnONP}$ seed treatments. Similar improvement in chlorophyll content has also been reported by Faizan et al. [36]. They have observed maximum chlorophyll content (measured as SPAD value) in tomato plant on $\mathrm{ZnONPs}$ treatment $\left(8 \mathrm{mg} \mathrm{L}^{-1}\right)$.

The applied ZnONPs ensured an increase in yield due to improvement in the yield attributing characters of the treated plants. The yield increase can be associated with the increase in the chlorophyll content leading to improved photosynthetic efficiency that can be specifically correlated with the enhancement in the soluble protein content, starch content, and dry mass [37].

The macronutrients (NPK) and micronutrient, i.e., Zinc (Zn) contents in shoot and roots of fodder maize were also enhanced by seed priming and coating with ZnONPs. This may be due to improved development of the root system observed as increased root biomass and length, thereby increasing the nutrient uptake. These results are also in accordance with the study of Kolencik et al. [37] who have reported significantly highest nitrogen content (17611 mg kg${ }^{-1}$ ) for ZnONPs $\left(2.6 \mathrm{mg} \mathrm{L}^{-1}\right)$ treatment compared to the control treatment in foxtail millet (Setaria italica L.). Similarly, foliar application of ZnONPs ( $30 \mathrm{mg} \mathrm{L}^{-1}$ ) in common bean plants increased the P and $\mathrm{Zn}$ content of leaves up to 0.34 and $23.9 \%$, respectively, compared to the control treatment [38]. Adhikari et al. [39] have also observed the highest content of $\mathrm{Zn}\left(38 \mathrm{mg} \mathrm{kg}^{-1}\right)$ in root and shoot tissues $\left(30 \mathrm{mg} \mathrm{kg}^{-1}\right)$ of maize treated with $0.5 \mathrm{ppm}$ zinc oxide nanoparticles.

The forage maize fodder quality parameters are critical for its use as fresh feed for the livestock. Improvement in the yield and quality of the fodder maize may be attributed to improved photosynthesis and other metabolic processes in maize [34]. Likewise, enhancement in the yield and quality of forage sorghum was observed by the application of micronutrients such as iron, zinc, and manganese [40]. Sharifi et al. [34] compared the foliar and seed priming treatments of bulk and nanoformulations of zinc and iron micronutrients and reported improved plant quality parameters including the P-content, biomass, crude protein, and soluble carbohydrates.

Priming and coating with different concentrations of ZnONPs significantly influenced the nutrient concentration in soil. This may be ascribed to nano-scale dimensions of the nano- $\mathrm{ZnO}$ formulation which improved the solubility and dispersion of insoluble nutrients in soil, leading to decreased soil absorption and fixation, and increased bioavailability [34]. The soil macronutrient like available nitrogen $(\mathrm{N})$, Phosphorous $(\mathrm{P})$, Potassium $(\mathrm{K})$, and zinc $(\mathrm{Zn})$ micronutrient contents were also increased in the rhizosphere soil of plants treated with ZnONPs. The increased soil available K, $\mathrm{P}$ and $\mathrm{Zn}$ contents in the rhizosphere soil may be attributed to enhanced root growth, higher production of the organic acids by the plant roots [41] and occurrence of P-solubilizing microbes [42] as indicated through 
greater alkaline and acid phosphatase activities which cumulatively led to decrease in the $\mathrm{pH}$ in near vicinity of the growing roots thus facilitating improved soil available $\mathrm{K}, \mathrm{P}$ and Zn contents. The enhancement in the soil N content in plants treated with ZnONPs must be due to enhanced microbial biomass or activity particularly the non-symbiotic N-fixer populations $[43,44]$ which were increased due to seed priming and coating treatments. These microbes could have led to fixation of the atmospheric N. Additionally, the higher dehydrogenase activity in the ZnONPs priming and coating treatments indicate accumulation of organic $\mathrm{N}$ in the form of microbial biomass [44]. Furthermore, as the actinobacterial population was also increased in these treatments, there will also be rise in the soil protease and urease activities [45] leading to higher N-transformation and availability though the same were not quantified in this report. Raliya and Tarafdar [46] and Raliya et al. [47] have also recorded enhancement in the microbial population and soil enzyme activities by the application of ZnONPs leading to mobilization of essential nutrients, i.e., soil $\mathrm{N}$ content. Zinc oxide nanoparticles also affect the soil P contents. An increased amount of residual $\mathrm{P}$ in the soil was observed after the harvest of sorghum plants in ZnONPs and zinc salt treatments compared to the control treatment [48]. The application of ZnONPs in the soil led to increased $\mathrm{Zn}$ concentrations in soil under maize cultivation [49].

The soil microbiological characteristics were also influenced by seed coating/priming treatments of maize seeds. The enhancement in the soil enzyme activities particularly the dehydrogenase enzyme activity - the enzyme involved in respiration and food mobilization can be attributed to the role of $\mathrm{Zn}$ as a cofactor of the dehydrogenase enzyme [50]. Similarly, Kumar et al. [51] have observed significantly higher dehydrogenase activity $\left(18.78 \mu \mathrm{g}\right.$ TPF formed/g of soil/h) on the application of nano- $\mathrm{ZnO}\left(40 \mathrm{mg} \mathrm{kg}^{-1}\right)$ as compared to the control treatment. Moreover, significantly increased acid and alkaline phosphatase activities have been reported on application of nano- $\mathrm{ZnO}\left(10 \mathrm{mg} \mathrm{L}^{-1}\right)$ in the rhizosphere of the cluster bean plant [46]. The soil microbial viable counts were also significantly increased in soil sampled from field plots belonging to ZnONPs priming and coating treatments. Kumar et al. [51] have reported similar results on the application of nano-ZnO. Likewise, Raliya and Tarafdar [46] have shown enhanced microbial populations on treatment with nano- $\mathrm{ZnO}\left(10 \mathrm{mg} \mathrm{L}^{-1}\right)$ in the rhizospheric soil of cluster bean.

The PCA results of this study showcased a strong association for vegetative, yield attributing, soil nutrient, and microbiological characteristics with both seed coating and priming treatments of Zn-source particularly ZnONPs. These results are in accordance to the study of Popovi 'c et al. [52] who have observed improvement in the seed emergence, plant height, spike length and grain weight plant ${ }^{-1}$ traits in wheat which were found to be associated with the seed priming treatment with ZnONPs. Likewise, another PCA analysis on the effect of soil application of urea crystals coated with Bacillus sp. augmented $\mathrm{ZnO}$ particles on wheat depicted that this treatment was the second best after the zinc sulphate coated urea treatment in the PCA score plots. Additionally, in a pot-culture study of Aziz et al. [53] on perennial ryegrass, the PCA revealed that the soil chemical and microbiological traits besides the dry matter and plant nutrient status were very well correlated and associated with $\mathrm{ZnO}$ nanoparticle treatment.

\section{Conclusions}

The application of nano- $\mathrm{ZnO}$ as seed polymer coating/priming treatment enhanced the vegetative growth, fodder yield, and fiber quality of the fodder maize (var. J-1006). Furthermore, ZnONPs coating or priming treatments also proved to be better to enhance the available zinc micronutrient in fodder maize crop (var. J-1006) cultivated under the field conditions. Thus, using a very low quantity of $\mathrm{ZnO}$ nanofertilizer through seed treatment can help reduce the application doses of zinc fertilizers and, thus, the wastage of conventional Zn-fertilizers. Furthermore, environmental hazards associated with the multiple/over-application of Zn-fertilizers can also be effectively addressed. Incidentally, the ZnONPs as Zn-fertilizers can help increase Zn-nutrient use efficiency in fodder crops specifically fodder maize cultivated under field conditions. 
Supplementary Materials: The following are available online at https: / www.mdpi.com/article/ 10.3390/agronomy11040729/s1, Table S1: Analysis of variance (ANOVA) for seed treatments, concentration of $\mathrm{Zn}$-source and Treatment $\times$ concentration for vegetative, yield attributing and quality parameters of fodder maize crop (variety J-1006) grown under field conditions, Table S2: Interaction effect of seed treatments and concentration of $\mathrm{Zn}$-source on vegetative, yield attributing and quality parameters of fodder maize crop (variety J-1006) grown under field conditions, Table S3: Analysis of variance (ANOVA) for seed treatments, concentration of Zn-source and Treatment $\times$ concentration for photosynthetic pigments of fodder maize crop (variety J-1006) grown under field conditions, Table S4: Interactive effect of seed treatments and concentration of Zn-source on photosynthetic pigments in fodder maize crop (variety J-1006) grown under field conditions, Table S5: Analysis of variance (ANOVA) for seed treatments, concentration of $\mathrm{Zn}$-source and Treatment $\times$ concentration for plant nutrient content of fodder maize crop (variety J-1006) grown under field conditions, Table S6: Effect of plant tissue type, seed treatments and concentration of Zn-source on plant nutrient content of fodder maize crop (variety J-1006) grown under field conditions, Table S7: Analysis of variance (ANOVA) for DAS, seed treatments, concentration of Zn-source and their interactions on soil nutrient content, enzymatic activities and soil microbial viable counts of fodder maize crop (variety J-1006) grown under field conditions, Table S8: Effect of DAS, seed treatments and concentration of Zn-source on soil nutrient content, and microbiological characteristics in fodder maize crop (variety J-1006) grown under field conditions.

Author Contributions: Conceptualization, A.K.; methodology, A.K., G.S.D. and M.S.T.; validation, M.T., A.K., A.S., G.S.D. and M.S.T.; formal Analysis, M.T. and A.K.; investigation, M.T. and A.S.; resources, A.K.; data curation, M.T., A.K.; writing—original draft preparation, M.T. and A.K.; writingreview and editing, A.K., G.S.D., K.K. and E.N.; visualization, A.K. and A.S.; supervision, A.K. and K.K.; project administration, A.K.; funding acquisition, A.K., O.K. and K.K. All authors have read and agreed to the published version of the manuscript.

Funding: This study was funded by Rashtriya Krishi Vikas Yojana (RKVY), Government of India, New Delhi, India. Additionally, the study was supported by VT2019-2021.

Institutional Review Board Statement: Not applicable.

Informed Consent Statement: Not applicable.

Data Availability Statement: The data are included in the article.

Acknowledgments: A.K. thanks the Director of Research, Punjab Agricultural University, Ludhiana, Punjab, India for allocation of funds in the RKVY scheme to carry out the research work.

Conflicts of Interest: The authors declare no conflict of interest.

\section{References}

1. Tariq, A.; Anjum, S.A.; Randhawa, M.A.; Ullah, E.; Naeem, M.; Qamar, R.; Ashraf, U.; Nadeem, M. Influence of Zinc Nutrition on Growth and Yield Behaviour of Maize (Zea mays L.) Hybrids. Am. J. Plant. Sci. 2014, 5, 2646-2654. [CrossRef]

2. Hacisalihoglu, G. Zinc (Zn): The last nutrient in the alphabet and shedding light on zn efficiency for the future of crop production under suboptimal zn. Plants 2020, 9, 1471. [CrossRef]

3. Mohan, S.; Singh, M.; Kumar, R. Effect of nitrogen, phosphorus and zinc fertilization on yield and quality of kharif fodder-A review. Agric. Rev. 2015, 36, 218. [CrossRef]

4. Kaya, C.; Higgs, D. Response of tomato (Lycopersicon esculentum L.) cultivars to foliar application of zinc when grown in sand culture at low zinc. Sci. Hortic. 2002, 93, 53-64. [CrossRef]

5. Tsonev, T.; Lidon, F.J.C. Zinc in plants-An overview. Emir. J. Food Agric. 2012, 24, 322-333.

6. Estrada-Urbina, J.; Cruz-Alonso, A.; Santander-González, M.; Méndez-Albores, A.; Vázquez-Durán, A. Nanoscale Zinc Oxide Particles for Improving the Physiological and Sanitary Quality of a Mexican Landrace of Red Maize. Nanomaterials 2018, 8, 247. [CrossRef]

7. Mašev, N.; Kutáček, M. The effect of zinc on the biosynthesis of tryptophan, indol auxins and gibberellins in barley. Biol. Plant. 1966, 8, 142-151. [CrossRef]

8. Suganya, A.; Saravanan, A.; Manivannan, N. Role of Zinc Nutrition for Increasing Zinc Availability, Uptake, Yield, and Quality of Maize (Zea mays L.) Grains: An Overview. Commun. Soil Sci. Plant. Anal. 2020, 51, 2001-2021. [CrossRef]

9. Kabir, A.H.; Swaraz, A.M.; Stangoulis, J. Zinc-deficiency resistance and biofortification in plants. J. Plant. Nutr. Soil Sci. 2014, 177, 311-319. [CrossRef] 
10. Joy, E.J.M.; Stein, A.J.; Young, S.D.; Ander, E.L.; Watts, M.J.; Broadley, M.R. Zinc-enriched fertilisers as a potential public health intervention in Africa. Plant. Soil 2015, 389, 1-24. [CrossRef]

11. Rengel, Z. Availability of Mn, Zn and Fe in the rhizosphere. J. Soil Sci. Plant. Nutr. 2015, 15, 397-409. [CrossRef]

12. Gangloff, W.J.; Westfall, D.G.; Peterson, G.A.; Mortvedt, J.J. Mobility of organic and inorganic zinc fertilizers in soils. Commun. Soil Sci. Plant. Anal. 2006, 37, 199-209. [CrossRef]

13. Alloway, B.J. Soil factors associated with zinc deficiency in crops and humans. Environ. Geochem. Health 2009, 31, 537-548. [CrossRef] [PubMed]

14. Bala, R.; Kalia, A.; Dhaliwal, S.S. Evaluation of Efficacy of ZnO Nanoparticles as Remedial Zinc Nanofertilizer for Rice. J. Soil Sci. Plant. Nutr. 2019, 19, 379-389. [CrossRef]

15. Janmohammadi, M.; Amanzadeh, T.; Sabaghnia, N.; Dashti, S. Impact of foliar application of nano micronutrient fertilizers and titanium dioxide nanoparticles on the growth and yield components of barley under supplemental irrigation. Acta Agric. Slov. 2016, 107, 265. [CrossRef]

16. Elhaj Baddar, Z.; Unrine, J.M. Functionalized-ZnO-Nanoparticle Seed Treatments to Enhance Growth and Zn Content of Wheat (Triticum aestivum) Seedlings. J. Agric. Food Chem. 2018, 66, 12166-12178. [CrossRef]

17. Neto, M.E.; Britt, D.W.; Lara, L.M.; Cartwright, A.; Dos Santos, R.F.; Inoue, T.T.; Batista, M.A. Initial development of corn seedlings after seed priming with nanoscale synthetic zinc oxide. Agronomy 2020, 10, 307. [CrossRef]

18. Itroutwar, P.D.; Govindaraju, K.; Tamilselvan, S.; Kannan, M.; Raja, K.; Subramanian, K.S. Seaweed-Based Biogenic ZnO Nanoparticles for Improving Agro-morphological Characteristics of Rice (Oryza sativa L.). J. Plant. Growth Regul. 2020, 39, 717-728. [CrossRef]

19. Acharya, P.; Jayaprakasha, G.K.; Crosby, K.M.; Jifon, J.L.; Patil, B.S. Nanoparticle-Mediated Seed Priming Improves Germination, Growth, Yield, and Quality of Watermelons (Citrullus lanatus) at multi-locations in Texas. Sci. Rep. 2020, 10, 1-16. [CrossRef]

20. Farooq, M.; Wahid, A.; Siddique, K.H.M. Micronutrient application through seed treatments-A review. J. Soil Sci. Plant. Nutr. 2012, 12, 125-142. [CrossRef]

21. Chatterjee, N.; Sarkar, D.; Sankar, A.; Pal, S.; Singh, H.B.; Singh, R.K.; Bohra, J.S.; Rakshit, A. On-farm seed priming interventions in agronomic crops. Acta Agric. Slov. 2018, 111, 715-735. [CrossRef]

22. Farooq, M.; Usman, M.; Nadeem, F.; Rehman, H.U.; Wahid, A.; Basra, S.M.A.; Siddique, K.H.M. Seed priming in field crops: Potential benefits, adoption and challenges. Crop. Pasture Sci. 2019, 70, 731-771. [CrossRef]

23. Davis, D.; Singh, S. ZnO Nanoparticles Synthesis by Sol-Gel Method and Characterization. Indian J. Nanosci. 2016, 4, 1-4.

24. Anderson, J.M.; Boardman, N. Studies on The Greening of Dark-Grown Bean Plants II. Development of Photochemical Activity. Aust. J. Biol. Sci. 1964, 17, 93. [CrossRef]

25. Lindsay, W.L.; Norvell, W.A. Development of a DTPA Soil Test for Zinc, Iron, Manganese, and Copper. Soil Sci. Soc. Am. J. 1978, 42, 421-428. [CrossRef]

26. Goering, H.K.; Van Soest, P.J. Forage Fiber Analyses (Apparatus, Reagents, Procedures, and Some Applications); Agriculture Research Service USDA: Washington, DC, USA, 1970.

27. Olsen, S.; Cole, C.; Watanabe, F.; Dean, L. Estimation of Available Phosphorous by Extraction with Sodium Bicarbonate; US Department of Agriculture: Washington, DC, USA, 1954.

28. Casida, L.E.; Klein, D.A.; Santoro, T. Soil dehydrogenase activity. Soil Sci. 1964, 98, 371-376. [CrossRef]

29. Tabatabai, M.A.; Bremner, J.M. Use of p-nitrophenyl phosphate for assay of soil phosphatase activity. Soil Biol. Biochem. 1969, 1 , 301-307. [CrossRef]

30. Chemingui, H.; Smiri, M.; Missaoui, T.; Hafiane, A. Zinc Oxide Nanoparticles Induced Oxidative Stress and Changes in the Photosynthetic Apparatus in Fenugreek (Trigonella foenum graecum L.). Bull. Environ. Contam. Toxicol. 2019, 102, 477-485. [CrossRef]

31. Jain, A.; Panwar, S.; Kang, T.W.; Jeon, H.C.; Kumar, S.; Choubey, R.K. Effect of zinc oxide concentration in fluorescent ZnS:Mn/ZnO core-shell nanostructures. J. Mater. Sci. Mater. Electron. 2014, 25, 1716-1723. [CrossRef]

32. Zakirov, M.I.; Semen'ko, M.P.; Korotchenkov, O.A. A simple sonochemical synthesis of nanosized ZnO from zinc acetate and sodium hydroxide. J. Nano Electron. Phys. 2018, 10, 4-7. [CrossRef]

33. Sturikova, H.; Krystofova, O.; Huska, D.; Adam, V. Zinc, zinc nanoparticles and plants. J. Hazard. Mater. 2018, 349, 101-110. [CrossRef] [PubMed]

34. Sharifi, R. Effect of seed priming and foliar application with micronutrients on quality of forage corn (Zea mays). Environ. Exp. Biol. 2016, 14, 151-156. [CrossRef]

35. Mahdieh, M.; Sangi, M.R.; Bamdad, F.; Ghanem, A. Effect of seed and foliar application of nano-zinc oxide, zinc chelate, and zinc sulphate rates on yield and growth of pinto bean (Phaseolus vulgaris) cultivars. J. Plant. Nutr. 2018, 41, 2401-2412. [CrossRef]

36. Faizan, M.; Faraz, A.; Yusuf, M.; Khan, S.T.; Hayat, S. Zinc oxide nanoparticle-mediated changes in photosynthetic efficiency and antioxidant system of tomato plants. Photosynthetica 2018, 56, 678-686. [CrossRef]

37. Kolenčík, M.; Ernst, D.; Komár, M.; Urík, M.; Šebesta, M.; Dobročka, E.; Černý, I.; Illa, R.; Kanike, R.; Qian, Y.; et al. Effect of foliar spray application of zinc oxide nanoparticles on quantitative, nutritional, and physiological parameters of foxtail millet (Setaria italica L.) under field conditions. Nanomaterials 2019, 9, 1559. [CrossRef] 
38. Salama, D.M.; Osman, S.A.; Abd El-Aziz, M.E.; Abd Elwahed, M.S.A.; Shaaban, E.A. Effect of zinc oxide nanoparticles on the growth, genomic DNA, production and the quality of common dry bean (Phaseolus vulgaris). Biocatal. Agric. Biotechnol. 2019, 18, 101083. [CrossRef]

39. Adhikari, T.; Kundu, S.; Rao, A.S. Zinc delivery to plants through seed coating with nano-zinc oxide particles. J. Plant. Nutr. 2016, 39, 136-146. [CrossRef]

40. Soleymani, A.; Shahrajabian, M.H. The Effects of Fe, Mn and Zn Foliar Application on Yield, Ash and Protein Percentage of Forage Sorghum in Climatic Condition of Esfahan. Int. J. Biol. 2012, 4, 92-96. [CrossRef]

41. Yang, Y.; Yang, Z.; Yu, S.; Chen, H. Organic acids exuded from roots increase the available potassium content in the rhizosphere soil: A rhizobag experiment in Nicotiana tabacum. HortScience 2019, 54, 23-27. [CrossRef]

42. Wu, F.; Li, J.; Chen, Y.; Zhang, L.; Zhang, Y.; Wang, S.; Shi, X.; Li, L.; Liang, J. Effects of Phosphate Solubilizing Bacteria on the Growth, Photosynthesis, and Nutrient Uptake of Camellia oleifera Abel. Forests 2019, 10, 348. [CrossRef]

43. Mahato, S.; Kafle, A. Comparative study of Azotobacter with or without other fertilizers on growth and yield of wheat in Western hills of Nepal. Ann. Agrar. Sci. 2018, 16, 250-256. [CrossRef]

44. Bageshwar, U.K.; Srivastava, M.; Pardha-Saradhi, P.; Paul, S.; Gothandapani, S.; Jaat, R.S.; Shankar, P.; Yadav, R.; Biswas, D.R.; Kumar, P.A.; et al. An environmentally friendly engineered Azotobacter strain that replaces a substantial amount of urea fertilizer while sustaining the same wheat yield. Appl. Environ. Microbiol. 2017, 83, 1-14. [CrossRef] [PubMed]

45. Ge, Y.; Schimel, J.P.; Holdena, P.A. Identification of soil bacteria susceptible to TiO2 and ZnO nanoparticles. Appl. Environ. Microbiol. 2012, 78, 6749-6758. [CrossRef] [PubMed]

46. Raliya, R.; Tarafdar, J.C. ZnO Nanoparticle Biosynthesis and Its Effect on Phosphorous-Mobilizing Enzyme Secretion and Gum Contents in Clusterbean (Cyamopsis tetragonoloba L.). Agric. Res. 2013, 2, 48-57. [CrossRef]

47. Raliya, R.; Saharan, V.; Dimkpa, C.; Biswas, P. Nanofertilizer for Precision and Sustainable Agriculture: Current State and Future Perspectives. J. Agric. Food Chem. 2018, 66, 6487-6503. [CrossRef]

48. Dimkpa, C.O.; White, J.C.; Elmer, W.H.; Gardea-Torresdey, J. Nanoparticle and ionic Zn promote nutrient loading of sorghum grain under low NPK fertilization. J. Agric. Food Chem. 2017, 65, 8552-8559. [CrossRef]

49. Liu, X.; Wang, F.; Shi, Z.; Tong, R.; Shi, X. Bioavailability of Zn in ZnO nanoparticle-spiked soil and the implications to maize plants. J. Nanoparticle Res. 2015, 17. [CrossRef]

50. Castillo-González, J.; Ojeda-Barrios, D.; Hernández-Rodríguez, A.; González-Franco, A.C.; Robles-Hernández, L.; López-Ochoa, G.R. Zinc metalloenzymes in plants. Interciencia 2018, 43, 242-248.

51. Kumar, A.; Rakshit, R.; Bhowmik, A.; Mandal, N.; Das, A.; Adhikary, S. Nanoparticle-induced changes in resistance and resilience of sensitive microbial indicators towards heat stress in soil. Sustainability 2019, 11, 862. [CrossRef]

52. Popović, V.; Ljubičić, N.; Kostić, M.; Radulović, M.; Blagojević, D.; Ugrenović, V.; Popović, D.; Ivošević, B. Genotype $\times$ Environment Interaction for Wheat Yield Traits Suitable for Selection in Different Seed Priming Conditions. Plants 2020, 9, 1804. [CrossRef]

53. Aziz, Y.; Shah, G.A.; Rashid, M.I. ZnO nanoparticles and zeolite influence soil nutrient availability but do not affect herbage nitrogen uptake from biogas slurry. Chemosphere 2019, 216, 564-575. [CrossRef] [PubMed] 